\title{
Original
}

\section{Effect of Ganoderman lucidum on Proliferation and Apoptosis of Pulmonary Microvascular Endothelial Cells in vitro}

\author{
Ruizhe QIaN ${ }^{1,2)}$, Luchun HuA ${ }^{3,4)}$, Toshiaki Kunimura ${ }^{1)}$, \\ Hironori NaKamura ${ }^{1)}$, Hiroshi ISHINO ${ }^{1)}$, Masanobu IRI $^{1}$, \\ Hisashi HosaKa ${ }^{1)}$, Fengdi $Z_{\mathrm{HAO}^{2)}}$, Guoping $\mathrm{Z}_{\mathrm{HANG}^{2}}{ }^{2}$, \\ Masao MORI ${ }^{5)}$, Zhong $\mathrm{W}_{\mathrm{ANG}^{5}}{ }^{5}$, Huiming $\mathrm{J}_{\mathrm{IN}^{2}}{ }^{2}$ \\ and Toshio Morohoshi ${ }^{1)}$
}

\begin{abstract}
Ganoderman lucidum is a well-known Chinese crude and traditional herb that has been used in clinical settings in East Asia. One of its active components is a polysaccharide. The purpose of this study was to examine the effects of different doses of Ganoderman lucidum on proliferation and apoptosis in cultured rat pulmonary microvascular endothelial cells (RPMEC). The cell proliferation cycle was established for the cultured RPMEC and any changes in the cell cycle or apoptosis were observed using flow cytometry. Cell proliferation began four days after administration of Ganoderman lucidum $(2.75 \mathrm{mg} / \mathrm{ml})$ and peaked at the day 7 . After $24 \mathrm{~h}$ culture, the quantity of cells in $G_{0}-G_{1}$ cycle had decreased $(p<0.05)$ while numbers in $G_{2}-\mathbf{M}$ cycle had increased $(p<0.05)$ in the low dose group. The quantity of cells in $G_{0}-G_{1}$ cycle decreased $(p<0.05)$ while numbers in $S$ cycle increased $(p<0.05)$ in the moderate dose group. The quantity of cells in $G_{0}-G_{1}$ cycle decreased $(p<0.01)$, while numbers in $G_{2}-\mathbf{M}$ cycle $(p<0.01)$ and $\mathbf{S}$ cycle $(p<0.05)$ increased in the high dose group. No significant change in apoptosis was observed in any of the groups. Our results suggest that Ganoderman lucidum may stimulate the proliferation of cultured RPMEC, and therefore play an important role in healing injuries and accelerating repair.
\end{abstract}

Key words : pulmonary microvascular endothelial cells, Ganoderman lucidum, cell cycle, apoptosis

\section{Introduction}

Ganoderman lucidum, a well-known Chinese crude and traditional herb, has been widely used as a medicinal or health-promotion product in China and other East Asian countries ${ }^{1-3)}$; its active components include a polysaccharide. Ganoderman lucidum is used for the treatment of hypertension, arteriosclerosis, hemorrhoids, symptoms of fatigue, cancer, diabetes, hepatitis, chronic bronchitis, arthritis, and asthma ${ }^{1,4,5)}$. It is also used as a sedative and

\footnotetext{
${ }^{1)}$ First Department of Pathology, Showa University School of Medicine, 1-5-8 Hatanodai, Shinagawa-ku, Tokyo 1428555, Japan.

${ }^{2}$ Department of Physiology and Pathophysiology, Fudan University Shanghai Medical Collage.

3) Second Department of Surgery, Showa University School of Medicine.

4) Department of Surgery, Fudan University Huashan Hospital.

5) Wakan Shoyaku Botany Institute.
} 
tranquilizer for dizziness and insomnia due to neurasthenia and as a tonic for symptoms of weakness or debility ${ }^{4,5)}$. Previous approaches using Ganoderman lucidum showed an improvement in microcirculation and infusion volumes of vital organs in primary hypertension patients ${ }^{6,7)}$. Ganoderman lucidum is also an effective inhibitory agent of platelet aggregation ${ }^{8}$, however, its efficacy has not been confirmed and its exact mechanism of action has not yet been determined.

Microvascular endothelial cells play a very important role in hypertension, arteriosclerosis, thrombosis and other cardiac diseases. However, to our knowledge no reports evaluating the effect of Ganoderman lucidum on proliferation and apoptosis of microvascular endothelial cells in vitro have been published. To determine the effect on microvascular endothelial cells, we added a solution of Ganoderman lucidum at different concentrations into the culture medium and observed the effect on proliferation and apoptosis of microvascular endothelial cells using flow cytometry in vitro.

\section{Material and Methods}

\section{Ganoderman lucidum}

Ganoderman lucidum was extracted from tablets (Wakan Shoyaku Botany Institute, Tokyo, Japan) using hot water and freeze-drying. Each tablet contains $55 \mathrm{mg}$ Ganoderman lucidum extracts (polysaccharide), equal to $1.375 \mathrm{~g}$ Ganoderman lucidum sporophores. The experimental solution of Ganoderman lucidum was produced by dissolving 50 Ganoderman lucidum tablets in $100 \mathrm{ml}$ DMEM (Sigma Chemical Co., St Louis, MO), resulting in a solution containing a final concentration of $27.5 \mathrm{mg}$ polysaccharide per milliliter, which was then agitated for 12 hours for complete dissolution at room temperature and filter sterilized using a $0.45 \mu \mathrm{m}$ filter. A control solution was prepared using the same matrix as the Ganoderman lucidum tablets (Wakan Shoyaku Botany Institute, Tokyo, Japan), and treated using the method described.

\section{Culture of rat pulmonary microvascular endothelial cells (RPMEC)}

We previously described the culture method for RPMEC ${ }^{9)}$. Briefly, male SD rats (weight range from $180 \sim 200 \mathrm{~g}$ ) were chosen, injected intra-peritoneally with pentobarbital natrium (dose : $1 \% 0.5 \mathrm{ml} / 100 \mathrm{~g} \mathrm{B.W.}$ ) and heparin (1000 $\mu / 100 \mathrm{~g} \mathrm{B.W.}$.). An in situ lung infusion with Hanks' balanced salt solution (HBSS) was performed. The side tissues of the rat's lung were cut into smaller pieces of $1 \mathrm{~mm}^{3}$, and 1-2 pieces per $\mathrm{cm}^{2}$ were placed in a flask and cultured for 60-70 hours using DMEM supplemented with $20 \%$ bovine serum. After adequate cell proliferation, the tissue pieces were removed and the culture medium changed until the cells proliferated into a confluent monolayer.

\section{Identification of RPMEC}

The morphology of RPMEC was round, polygonal or spindle form (Giemsa staining), and stained positive for factor VIII-related antigen (DAKO) and CD31 (DAKO) using immunohistochemical staining. Non-endothelial cells represented less than $5 \%$ of the total cells.

\section{Examination by flow cytometry}

The cell cycle and apoptosis of RPMEC were examined using the fluorescent stain PI 
(propidium iodide). After $24 \mathrm{~h}$ cultivation, the cells were harvested by trypsinization, followed by addition of HBSS at $\mathrm{pH} 7.4$ to adjust the cells to $10^{4} / \mathrm{ml}$. For a total of $10^{4}$ cells $5 \mu 1$ of PI was used. A wavelength of $48 \mathrm{~nm}$ for red fluorescence was used for flow cytometry (Facs Calibur, Becton Dickinson, USA), and the percentage of cells for each cell cycle stage and apoptosis using a total of 5000 cells was analyzed using the MODFITLT for mac vl.01 and CELLQUEST programs.

\section{Incubating RPMEC with Ganoderman lucidum}

The quantity of RPMEC (2nd generation) was adjusted to $10^{5} \mathrm{in} 10 \mathrm{ml}$ medium per culture flask. As previously reported ${ }^{6}$, $0.1 \mathrm{ml}$ Ganoderman lucidum solution (containing $2.75 \mathrm{mg}$ polysaccharide) was added to each flask in the low-dose group, $0.4 \mathrm{ml}$ (containing $11 \mathrm{mg}$ polysaccharide) in the moderate-dose group, and $0.8 \mathrm{ml}$ (containing $22 \mathrm{mg}$ polysaccharide) in the high-dose group. Control solution $(0.4 \mathrm{ml})$ was added to each culture flask in negative control group (the preliminary work showed that there were no differences between doses $0.1 \mathrm{ml}, 0.4 \mathrm{ml}$ and $0.8 \mathrm{ml}$ of control solution). Culture medium was then added to each flask to a final volume of $10 \mathrm{ml}$ and incubated for 24 hours before examining cell cycle and apoptosis by flow cytometry.

\section{Determination of the cell growth curve}

Day 1: A suspension containing $84 \mathrm{ml}$ of cells (first generation) was prepared. Two milliliters of the suspension were added to each well of seven 6-well plates at a final concentration of $0.4 \times 10^{5} / \mathrm{ml}$. One of the 6-well plates contained three wells used as the control group (C-group) and the rest were the experimental group (E-group).

Day 2: Control solution $(0.2 \mathrm{ml})$ was added to each well of the $\mathrm{C}$-group and the same volume of Ganoderman lucidum solution was added to each well of the $\mathrm{E}$ group.

Cells were harvested from one six-well plate by trypsinization using $1 \mathrm{ml}$ of $0.25 \%$ trypsin and then counted on days $3 \sim 8$ and the final 6-well plate was counted on day 9 .

The culture media was changed throughout the experiment and replaced as described for day 2. The experiment was repeated three times and the average number of cells in groups $\mathrm{C}$ and $\mathrm{E}$ were calculated for each time point. Growth curves for both the experimental and control groups were plotted.

\section{Statistical analysis}

The results of the experiments were statistically analyzed by rank-sum test and test.

\section{Results}

Effect of Ganoderman lucidum on growth of RPMEC

Ganoderman lucidum accelerates the proliferation of RPMEC. Compared with the control group, the quantity of cells at days 4 and 8 had increased significantly $(p<0.05)$ while the quantity of cells on days 5, 6 and 7 increased to a more significant degree $(\mathrm{p}<0.01$, Fig. 1)

Effects of different doses of Ganoderman lucidum on the cell cycle of RPMEC in vitro

The results showed that compared with the control group, the quantity of cells in $\mathbf{G}_{0^{-}}$ $\mathbf{G}_{1}$ cycle decreased $(p<0.05)$, while those in $\mathbf{G}_{2}-\mathbf{M}$ cycle increased $(p<0.05)$ significantly 


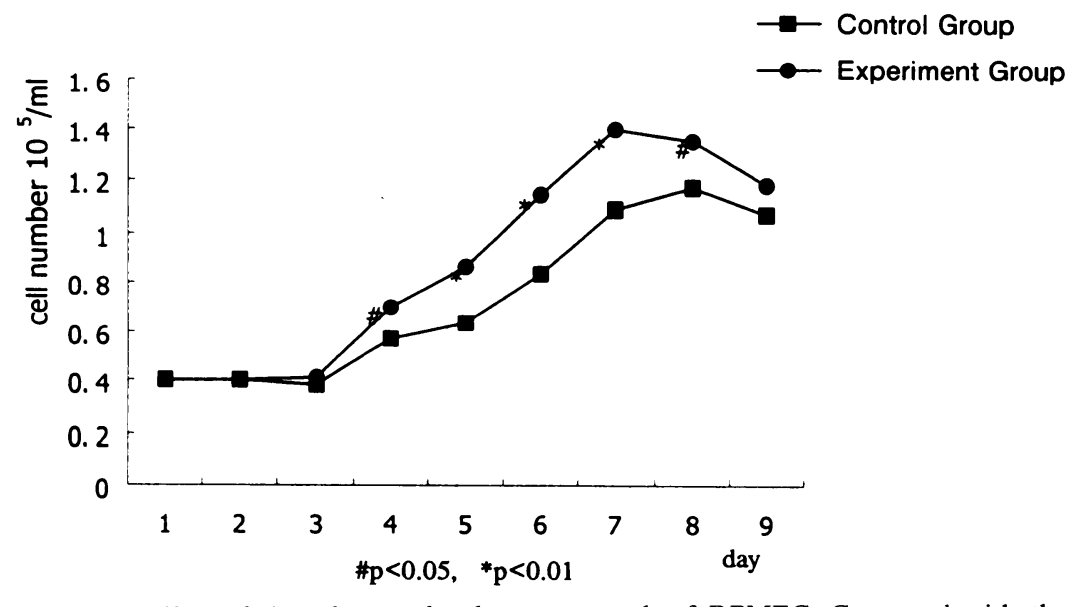

Fig. 1. Effect of Ganoderman lucidum on growth of RPMEC. Compared with the control group, the quantities of cells at days 4 and 8 increased significantly $(\mathrm{p}<0.05)$ and on days 5,6 and 7 increased to a more significant degree $(\mathrm{p}<0.01)$.

Table 1. Effect of Ganoderma Lucidum on the cell cycle of RPMEC in vitro

\begin{tabular}{|c|c|c|c|c|c|}
\hline \multirow{2}{*}{ Group } & \multirow{2}{*}{ Number } & \multicolumn{4}{|c|}{ Cell Cycle Analyses with Flow Cytometry } \\
\hline & & $\mathbf{G}_{0} \sim \mathbf{G}_{1}(\%)^{\#}$ & $\mathbf{G}_{2}-\mathbf{M}(\%)=$ & $\mathbf{S}(\%)$ & \\
\hline \multirow[t]{2}{*}{ Low dose group } & 9 & $83.31^{*}$ & $13.81^{*}$ & 5.38 & · \\
\hline & & $(80.24-84.88)$ & $(11.43-14.60)$ & $(3.69-5.82)$ & \\
\hline \multirow[t]{2}{*}{ Moderate dose group } & 9 & $79.93^{*}$ & $13.03^{*}$ & $7.30^{*}$ & \\
\hline & & $(78.05-82.30)$ & $(10.72-13.57)$ & $(6.50-8.87)$ & \\
\hline \multirow[t]{2}{*}{ High dose group } & 9 & $76.61^{* *}$ & $14.01^{* *}$ & $8.61^{*}$ & \\
\hline & & $(73.55-78.65)$ & $(12.77-18.65)$ & $(7.58-10.59)$ & \\
\hline \multirow[t]{2}{*}{ Control group } & 10 & 86.86 & 9.92 & 4.61 & \\
\hline & & $(86.45-88.39)$ & $(7.62-11.68)$ & $(3.00-6.61)$ & \\
\hline
\end{tabular}

"median $(25 \%-75 \%)$

Compare with control group ${ }^{*} \mathrm{p}<0.05,{ }^{* *} \mathrm{p}<0.01$

in the low-dose group. This suggested that mitosis of microvascular endothelial cells became active after the addition of Ganoderman lucidum. In the moderate-dose group, a significant reduction of the quantity of cells in $G_{0}-G_{1}$ cycle $(p<0.05)$ was observed. Cells in $G_{2}-M$ cycle increased but not significantly when compared with the control group. Cells in the $\mathrm{S}$ cycle increased significantly $(\mathbf{p}<0.05)$ revealing that a moderate-dose of Ganoderman lucidum promoted DNA synthesis of microvascular endothelial cells. Most significant was that the quantity of cells in $G_{0}-G_{1}$ cycle decreased $(p<0.01)$, while cells in the $G_{2}-M$ cycle $(p<0.01)$ and $S$ cycle increased $(p<0.05)$ in the high-dose group. This suggested that high doses of Ganoderman lucidum can promote the synthesis of DNA and mitosis of microvascular endothelial cells. The details are shown in Table 1. 
Table 2. Effect of Ganoderma Lucidum on apoptosis of RPMEC in vitro

\begin{tabular}{lcc}
\hline \multicolumn{1}{c}{ Group } & Number & Apoptosis percentage $(\%)^{\#}$ \\
\hline Low dose group & 9 & $3.70(2.66-5.22)$ \\
Moderate dose group & 9 & $4.78(2.42-6.16)$ \\
High dose group & 9 & $4.96(2.04-8.90)$ \\
Control group & 10 & $2.64(1.91-5.30)$ \\
\hline m & &
\end{tabular}

"median $(25 \% \sim 75 \%)$

\section{Effect of Ganoderman lucidum on apoptosis of RPMEC in vitro}

The results of flow cytometry showed that no significant difference of the percentage of cells undergoing apoptosis was found between groups receiving different doses and the control group. The details are shown in Table 2 .

\section{Discussion}

The efficacy of Ganoderman lucidum as an anticancer and tonic agent has been recognized for many years. It has been reported to have the following pharmacological effects : anticancer, antihypertensive, immunomodulatory, neuroactive, antihistamine, stabilization of mast cells, suppression of cough, hypoglycemic action, reduction of smooth muscle contraction, and antihepatotoxic action against $\mathrm{CCl}_{4}{ }^{5,10-17)}$.

The efficacy of Ganoderman lucidum for cells in vitro has usually been studied in tumor cells. It has been demonstrated that Ganoderman lucidum constitutively inhibited transcription factors (e.g. nuclear factor kappa B and AP-1) in breast MDA-MB-231 and prostate PC-3 cancer cells, which resulted in the inhibition of expression of urokinase-type plasminogen activator (UPA) and its receptor UPAR. Ganoderman lucidum suppressed cell adhesion and cell migration of highly invasive breast and prostate cancer cells suggesting a role in the reduction of tumor invasiveness ${ }^{18,19)}$. Ganoderman lucidum was also found to inhibit the growth of human hepatoma Huh-7 cells, but not Chang liver cells, a normal human liver cell line ${ }^{3)}$. Ganoderman lucidum inhibited cell proliferation in a dose- and time-dependent manner, which might be mediated through up-regulation of p21/Waf 1 and down-regulation of cyclin D1. Furthermore, Ganoderman lucidum could directly induce apoptosis in MCF-7 cells, possibly through an up-regulation of a pro-apoptotic Bax protein ${ }^{2)}$. However, to our knowledge there has been no report to date on the pharmacological efficacy of Ganoderman lucidum in vascular endothelial cells.

Our study demonstrated that Ganoderman lucidum improves the proliferation of RPMEC. Cell proliferation began on day 4 after administration of Ganoderman lucidum ( $2.75 \mathrm{mg} /$ $\mathrm{ml}$ ), and peaked at day 7 when compared with the control. Flow cytometry results showed that Ganoderman lucidum stimulates the proliferation of RPMEC after $24 \mathrm{~h}$ of culture. Characteristically a low dose of Ganoderman lucidum $(0.275 \mathrm{mg} / \mathrm{ml})$ increased the quantity of cells in the $\mathrm{G}_{2}-\mathrm{M}$ cycle significantly, a moderate dose $(1.1 \mathrm{mg} / \mathrm{ml})$ increased cells in the $\mathrm{S}$ cycle, and a high dose $(2.2 \mathrm{mg} / \mathrm{ml})$ increased cells in the $\mathrm{G}_{2}-\mathrm{M}$ as well as $\mathrm{S}$ cycle. Thus it can be seen, Ganoderman lucidum can increase the synthesis of DNA and mitosis of RPMEC in vitro, and a high dose is the most significant in all experimental groups. However, no significant changes in apoptosis were found in any of the different dosage groups. 
Our study suggested that the effect of Ganoderman lucidum on stimulating the proliferation of cultured RPMEC is useful in accelerating its repair after injury. It plays an important role in maintaining the smoothness and integrity of microvessel wall and preventing thrombosis.

\section{References}

1) Kimura $Y$, Taniguchi $M$ and Baba $K$ : Antitumor and antimetastatic effects on liver of triterpenoid fractions of Ganoderman lucidum : mechanism of action and isolation of an active substance. Anticancer Res 22 : 33093318 (2002)

2) Hu HB, Ahn NS, Yang XL, Lee YS and Kang KS : Ganoderman lucidum extract induces cell cycle arrest and apoptosis in MCF-7 human breast cancer cell. Int $J$ Cancer 102 : 250-253 (2002)

3) Lin SB, Li CH, Lee SS and Kan LS: Triterpene-enriched extracts from Ganoderman lucidum inhibit growth of hepatoma cells via suppressing protein kinase $\mathrm{C}$, activating mitogen-activated protein kinases and G2-phase cell cycle arrest. Life Sci $72: 2381-2390$ (2003)

4) Xie Z and Huang X: In : Dictionary of Traditional Chinese Medicine (Eds), The Commercial Press. Ltd., Hong Kong, p 201 (1988)

5) Wu TS, Shi LS and Kuo SC: Cytotoxicity of Ganoderman lucidum triterpenes. J Nat Prod 64:1121-1122 (2001)

6) Jin HM, Zhang GP and Qian RZ: Effect of Ganoderman lucidum combined with anti-hypertension therapy on blood sugar, plasma NO, microcirculation and hemorheology in treatment of refractory hypertension. Microcirculatory aspect of Asian traditional medicine, Niimi H, Patumraj S, Tigno XT and Xiu RJ (Eds), Monduzzi Editore, Bologna, pp 101-107 (1998)

7) Jin HM, Zhang GP, Cao $X$ and Zhang $M$ : Treatment of hypertension by Linzhi combined with hypotensor and its effects on arterial, arteriolar and capillary pressure and microcirculation. In : Microcirculatory approach to Asian traditional medicine, Niimi H, Patumraj S, Tigno XT and Xiu RJ (Eds), Elsevier, Amsterdam, pp 131-138 (1996)

8) Tao J and Feng KY : Experimental and clinical studies on inhibitory effect of Ganoderman lucidum on platelet aggregation. J Tongji Med Univ 10 : 240-243 (1990)

9) Zhang M, Cao X, Liu QH, Qian RZ, Zhang GP and Jin HM: Delayed effect of low concentration of $\mathrm{H}_{2} \mathrm{O}_{2}$ on pulmonary microvascular endothelial cells---Apoptosis. Zhongguo Bing Li Sheng Li Za Zhi 15: 28-32 (1999)

10) Bao XF, Wang XS, Dong Q, Fang JN and Li XY : Structural features of immunologically active polysaccharides from Ganoderman lucidum. Phytochemistry $59:$ 175-181 (2002)

11) Hack-Frenascho $M$, Kino $K$, Sone $T$ and Jardieu P: Ling Zhi-8: a novel $T$ cell mitogen induces cytokine production and upregulation of ICAM-1 expression. Cell Immunol 150 : 101-113 (1993)

12) Cheung WM, Hui WS, Chu PW, Chiu SW and Ip NY: Ganoderma extract activates MAP kinases and induces the neuronal differentiation of rat pheochromocytoma PC12 cells. FEBS Lett $486: 291-296$ (2000)

13) Wang SY, Hsu ML, Hsu HC, Tzeng CH, Lee SS, Shiao MS and Ho CK: The anti-tumor effect of Ganoderman lucidum is mediated by cytokines released from activated macrophages and $\mathrm{T}$ lymphocytes. Int $\mathrm{J}$ Cancer $70: 699-705$ (1997)

14) Zhang $Q$ and Lin Z : Study on antitumor activity and mechanism of Ganoderma polysaccharides B. Zhongguo Zhong Xi Yi Jie He Za Zhi 19 : 544-547 (1999)

15) Kim HS, Kacews $S$ and Lee BM : In vitro chemopreventive effect of plant polysaccharides (Aloe barbadensis miller, Lentinus edodes, Ganoderman lucidum and Coriolus versicolor). Carcinogenesis 20 : 1637-1640 (1999)

16) Lee JM, Kwon H, Lee W, Lee SY, Baek SJ and Surh YJ : Inhibition of lipid peroxidation and oxidative DNA damage by Ganoderman lucidum. Phytother Res 15 : 245-249 (2001)

17) Zhu HS, Yang XL, Wang LB, Zhao DX and Chen L: Effects of extracts from sporoderm-broken spores of Ganoderman lucidum on HeLa cells. Cell Biol Toxicol $16: 201-206$ (2000)

18) Sliva D : Ganoderman lucidum (Reishi) in cancer treatment. Integr Cancer Ther 2:358-364 (2003)

19) Sliva D, Labarrere C, Slivova V, Sedlak M, Lloyd FP Jr and Ho NW: Ganoderman lucidum suppresses motility of highly invasive breast and prostate cancer cells. Biochem Biophys Res Commun 298: 603-612 (2002) 